UDK 579.262

МРНТИ 34.27.23

DOI: https://doi.org/10.37788/2021-3/100-105

\author{
S.S. Karpova ${ }^{1}$, A.K. Ospanova ${ }^{1}$ \\ ${ }^{1}$ Innovative University of Eurasia, Kazakhstan \\ *(e-mail: light1121@mail.ru)
}

\title{
Investigation of the dependences of the rheology of calcium alginate solutions on concentration, temperature and shear rate
}

The main problem: The rheological properties of calcium salts are of theoretical and practical interest for a modern researcher. The theoretical interest is primarily related to the search for general patterns and manifestations of the rheological properties of solutions of calcium salts. The practical component is based on the search for patterns and dependencies of the properties of solutions on the structure and composition of the object of study. Such chemicals as calcium salts are of particular practical interest, they are widely used in various fields, such as the food, chemical and pharmacological industries. Hydrophilic high-molecular solutions of alginates, namely calcium alginate, are actively used in the preparation of soft dosage forms, the manufacture of jelly masses in confectionery, act as thickeners in the food industry. They are characterized by a fairly high percentage of viscosity at low concentrations, bioavailability, prolonging effect, absence of irritating properties, biocompatibility with many polymers, which is especially important in the pharmaceutical industry and medicine. The use of calcium salts for these purposes is currently very promising, since these organic salts have a number of unique properties associated with gelation.

Purpose: This paper contains the results of studying the features of the rheology of calcium alginate solutions. A concentration range of 0.1-0.7 \% was chosen for the studies, which is sufficient to avoid gelation at room temperature. The dependence of viscosity on concentration, temperature (in the range of $25-45^{\circ} \mathrm{C}$ ) and shear rate were studied.

Methods: Analysis of theoretical sources, observation, comparison of results. The rheological characteristics of the obtained substances were studied using a capillary viscometer. The measurements were carried out in the temperature range of $25-45^{\circ} \mathrm{C}$.

Results and their significance: it was found that there is a significant dependence of viscosity on concentration and temperature. For concentrations of $0.3-0.7 \%$, a similar type of dependence is observed, in contrast to solutions with a concentration of $0.1 \%$. Explanations of these dependencies were proposed.

Keywords: calcium alginate, solution, viscosity, rheology.

\section{Introduction}

The chemistry of macromolecular compounds has recently been of particular interest due to its rapid development and active use in various industries. It gets the greatest application in food and pharmacological directions. How to do it correctly, solutions of high molecular weight compounds are stable systems, which, however, can break their stability under certain conditions. This can lead to salting out, gelling, coacervation or gelation [1]. It should be noted that the ability to gel, as a rule, is due to the fact that alginates are polyelectrolytes, which explains their high water-holding capacity. In a solvent (usually water), the iogenic groups of polyelectrolytes dissociate to form charged units and low molecular weight counterions. Likely charged links of the polymer network repel each other, in connection with which, the chains, initially rolled into balls, are strongly stretched. Thus, the gel swells, significantly increasing in size and absorbing water [2].

The feature of the rheology of calcium alginate can be considered as a feature of the manifestation of its structure in aqueous solutions, in which a complex multilevel system is formed, which is of interest to the researcher. Like the majority of actively used high molecular weight compounds, its structure is fairly well established. It is a crystalline calcium salt of alginic acid with the chemical formula $\mathrm{C}_{12} \mathrm{H} 14 \mathrm{O}_{12} \mathrm{Ca}$ [3].

Calcium alginate has the number E404 and is included in the list of food additives allowed for use in the food industry in Kazakhstan as an adjuvant. As a rule, the industry produces water-soluble versions of alginates, a characteristic feature of which is the ability to form viscous solutions, due to which they are widely used as thickeners. A distinctive feature of calcium alginate is the neutrality of its effects on the body. Unlike most alginates, it has no aftertaste, odor and does not disturb the balance of calcium salts in the body by binding and excreting calcium from the body [4]. It is generally accepted that the ability to gel in solutions of calcium salts is due to the following mechanism: the conformational transition "spiral - coil" during cooling of an aqueous solution of calcium alginate, where the molecules are distributed homogeneously. When a suitable polymer concentration is reached, a macroscopic gel (three-dimensional network) is created, while at an insufficient concentration, local aggregates and individual macromolecules are formed. The density of crosslinking and the formation of a three-dimensional network of the gel is determined by the final concentration of calcium salts, which have successfully passed into solution [5]. Also, there are methods to shorten the structuring time of calcium alginate. The so-called methods of "internal gelling", in which cross-linking agents are introduced into 
calcium alginate, for example, insoluble salts of sodium and sparingly soluble carboxylic acid [6]. As a rule, the process of dissolution of a high-molecular compound occurs in 2 stages, which can be seen in Scheme 1 [7].

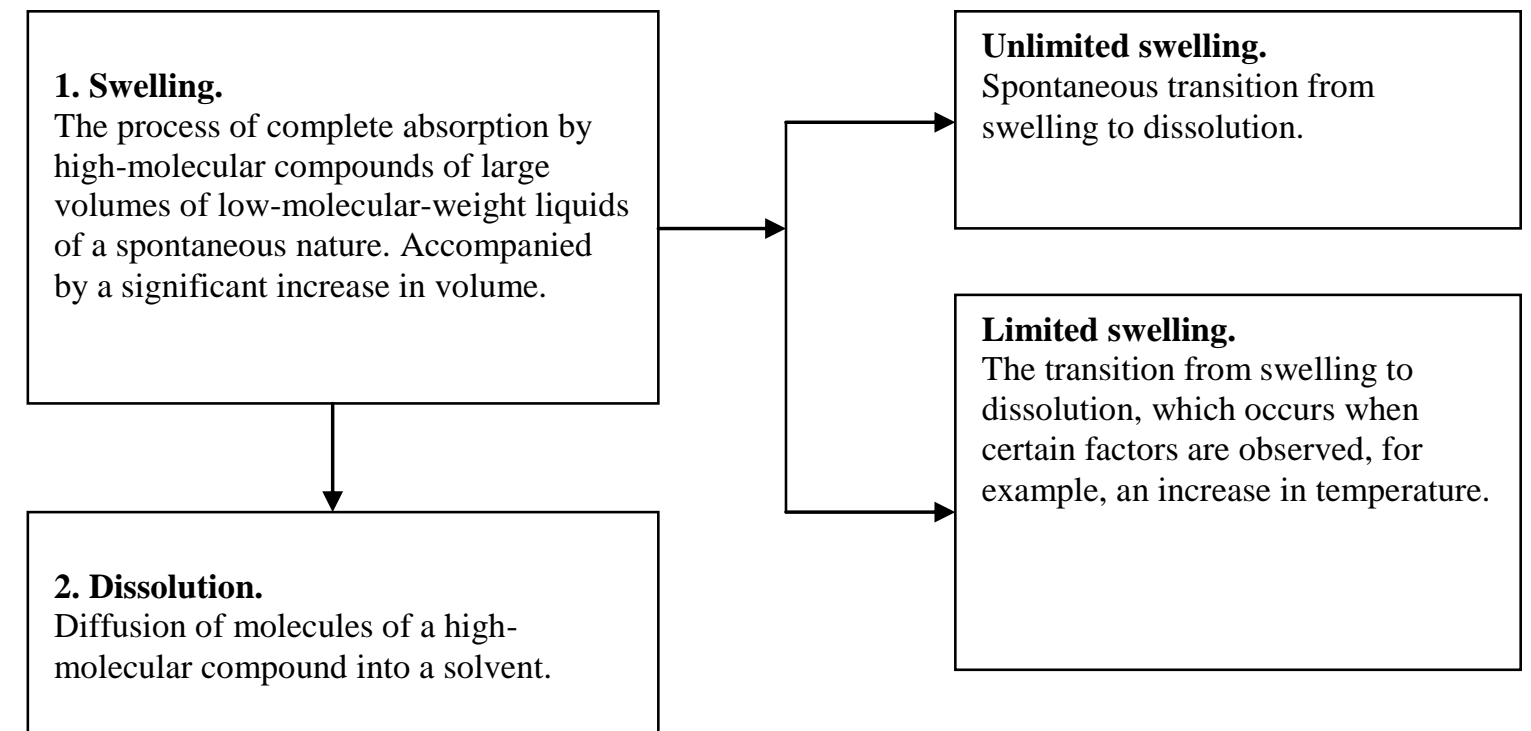

Scheme 1 - Stages of dissolution of high molecular weight substances.

The three main parameters that determine and limit the solubility of calcium alginate in water are: $\bullet$ The $\mathrm{pH}$ value of the solvent. Affects the reactivity of acid residues, leading to the formation of an "alginic acid gel" • Ionic strength of the solution. Determines the salting-out effects of those cations that are non-gelling. It has a great influence on the distribution of the polymer chain of alginate, which affects its solubility. $\cdot$ Solubilization of alginates. Limits the environment of gelling ions. Caused by the "hardness" of the water. Solutions of highmolecular compounds lose their stability under certain conditions, which is shown in Scheme 2.

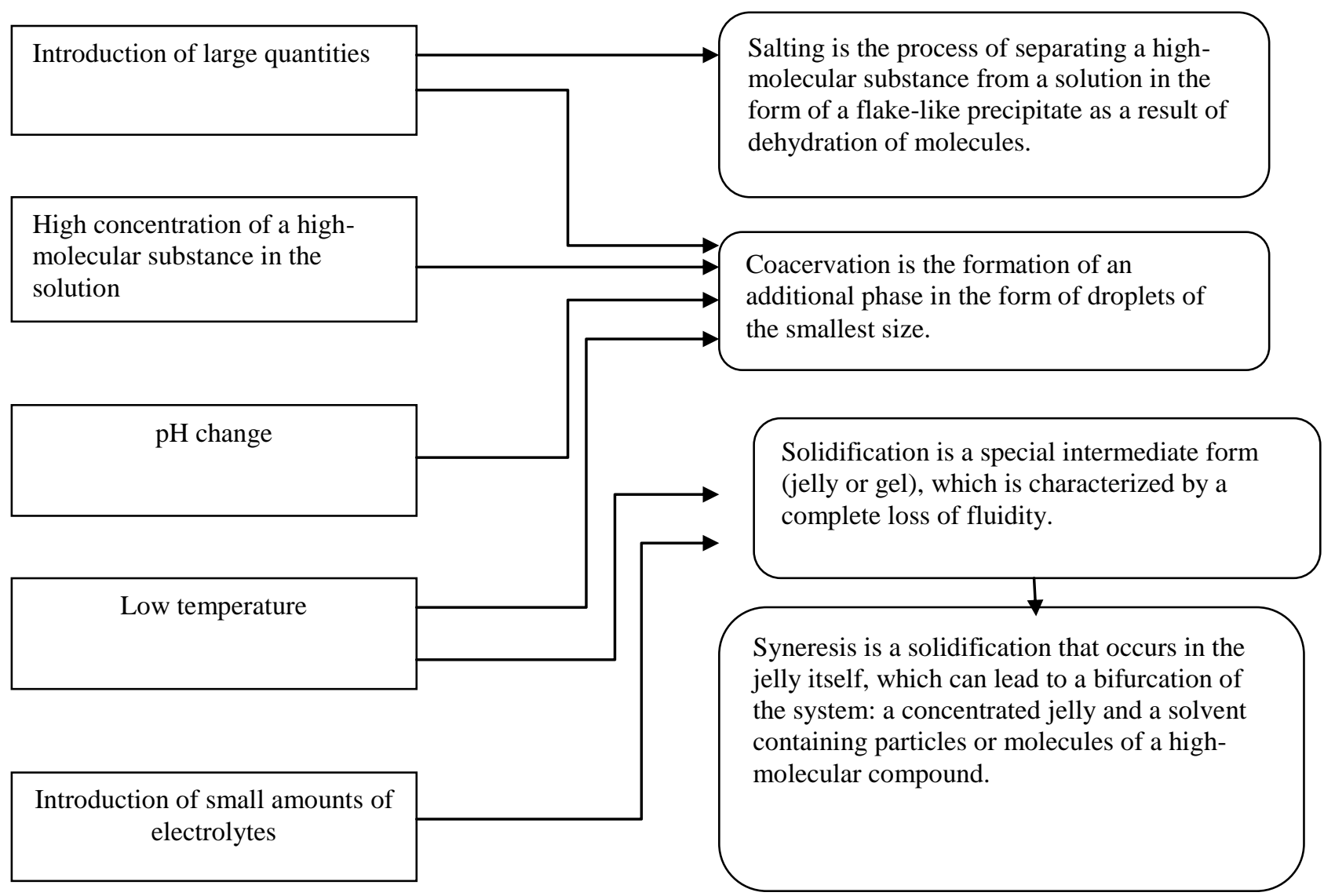

Scheme 2 - Types of instability of solutions of high-molecular compounds and factors influencing it [8]. 


\section{Materials and methods}

In this work, we used soluble calcium alginate of analytical grade (manufactured by Titan Biotech, India). For the analysis, a finely dispersed fraction was used, for which the weighed portion was pre-sieved through a set of sieves [9]. The particle size was in the range $0.11-0.19 \mathrm{~mm}$. The concentrations of the solutions selected for the study provide stable gelation at temperatures from $25^{\circ} \mathrm{C}$. The concentration of solid gel formation is $1.5-2 \%$ [10]. Based on this fact, the upper concentration value was chosen $0.7 \%$, since this concentration allows the viscosity to be measured using a capillary viscometer. At a higher concentration, the solution loses its fluidity. The lowest concentration - $0.1 \%$ was also chosen on the basis of literature data confirming that solutions with a concentration of less than $0.1 \%$ are viscous Newtonian liquids [11]. Solutions with a concentration of $0.1 ; 0.3 ; 0.5$; and $0.7 \%$ were prepared according to the well-known method [12]: the weighed portion was poured with a certain amount of distilled water $(\mathrm{pH} 5.6-5.8)$ with continuous stirring on a magnetic stirrer. This mixture was mixed for 5 minutes, then left for a day, 7 or 30 days. After the required time elapsed, the resulting mixture was heated in a water bath and brought to a boil on an electric stove. Then the resulting solutions are cooled naturally for several hours. The rheological characteristics of the obtained substance were carried out on a capillary viscometer. The measurements were carried out at three temperatures of 25,35 , and $45^{\circ} \mathrm{C}$. The choice of the lowest temperature is based on the information that stable gelation of calcium alginate occurs at a temperature of $25^{\circ} \mathrm{C}$ [10]. The shear rate was controlled by changing the capillary diameter of the viscometer.

\section{Results}

The most important property that was evaluated in the first place was the structural completeness of the solutions. Based on the fact that the process of hydration interaction of water on most of the polymer macromolecule can be quite long and not end in a day, it was decided to conduct additional research a week and 30 days after its preparation and cooling. The curves shown in Figure 1 illustrate the greatest changes exactly one month after preparation, especially for more concentrated solutions. This confirms the assumption that the processes of internal organization in calcium alginate solutions are a long-term process. In this connection, all other studies were carried out with solutions that had a period of at least a month.

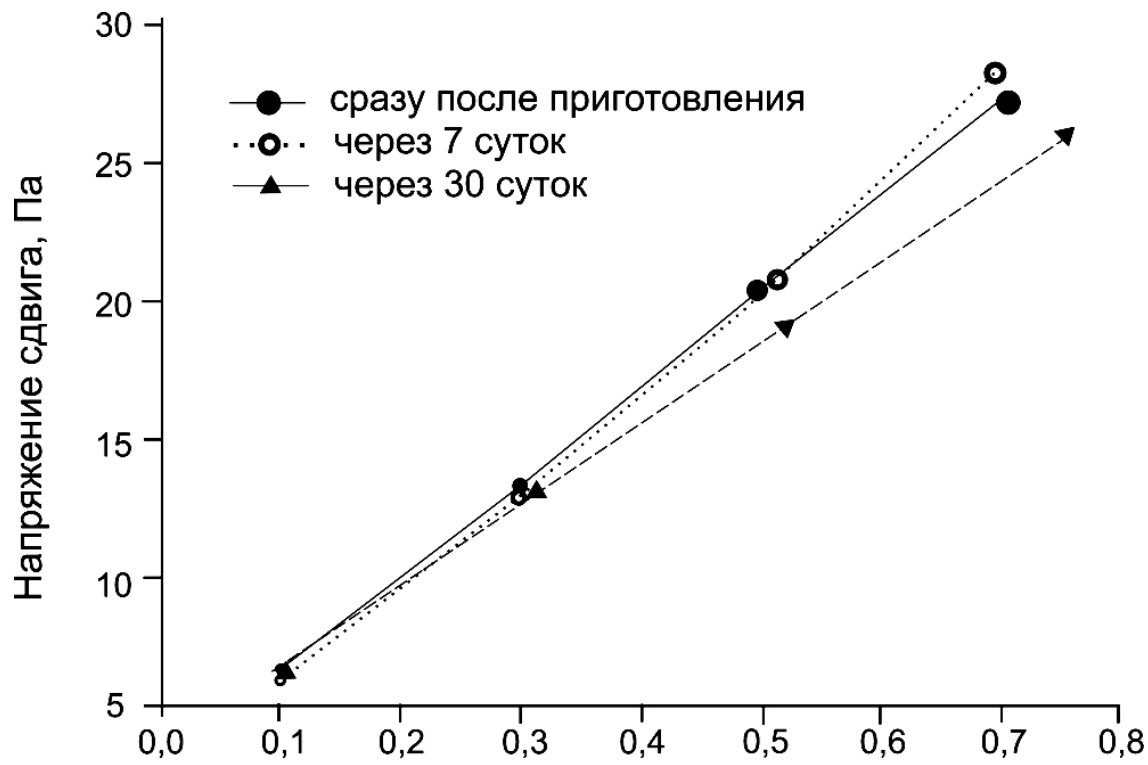

Figure 1 - Changes in the rheological properties of calcium alginate over time.

\section{Discussion}

The rise in complex viscosity shown in Figure 1 is primarily due to the formation of a gel structure. The dependence of viscosity on concentration, which shows significant changes in the characteristics of solutions at different shear rates, is shown in Figure 2. Of particular interest in this graph is the $0.3 \%$ point. This confirms the idea of interparticle interactions in the creation of a homogeneous organization. A direct linear dependence is observed only for a shear rate of $\approx 1000 \mathrm{~s}-1$. Thus, with the help of the graph, it is possible to confirm the theory of uneven destruction of the polymer structure at different shear rates. After analyzing the data obtained using the viscometer, it is possible to note the following. At a temperature of $25-33^{\circ} \mathrm{C}$ and at a shear rate of $300 \mathrm{~s}-1$, the dependence is polyextremal, the maximum is observed at a concentration of $0.3 \%$, and then linearly increases, rising with concentration. 


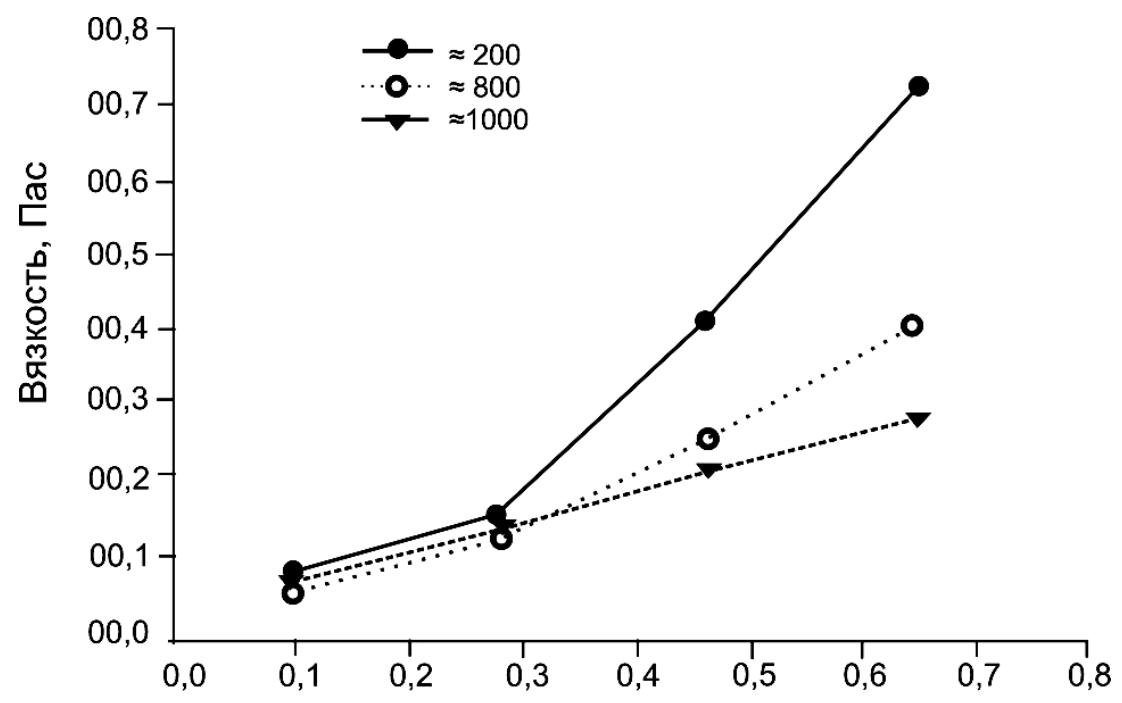

Figure 2 - Dependence of the difference of solutions on concentration for different shear rates (s-1).

From the data obtained, it can be concluded that each range of polymer concentrations can be considered as an independent rheological system. An explanation of this behavior of high-molecular compounds is given by R.D. Fogelson and E.R. Likhachev in the article for the journal of theoretical physics. This is due to the presence of special critical temperature regions. In particular, for calcium alginate solutions, such areas are a temperature of $45-35^{\circ} \mathrm{C}$. This explains the nonlinearity of the temperature dependence in the range of $25-45^{\circ} \mathrm{C}$. With an increase in concentration, a greater number of organizations of calcium alginate molecules also appear, as mentioned above. Thus, a conclusion is made about the nonlinear interactions of shear rate, temperature and concentration.

\section{Conclusion}

When analyzing literature data, as well as research results, we can conclude the following: 1. From the point of view of rheology, calcium alginate solutions are complex multilevel structural organizations. 2. Features of the structure of polymer solutions depend on their concentration, temperature and concentration of solutions. 3. The destruction of the polymer structure in solutions occurs unevenly at different shear rates.

\section{THE LIST OF SOURCES}

1 Кирсанов Е.А., Матвеенко В.Н. Ньютоновское поведение структурированных систем. Москва, 2016. $384 \mathrm{c}$.

2 Муратова Е.И., Смолихина П.М. Реология кондитерских масс. Тамбов, 2013. - 188 с.

3 Sousa A.M., Borges J., Silva A.F., Goncalves M.P., Influence of Extraction Processing on Rheological and structural properties of calcium // Carbohydrate Polymers. 2013, Vol.96. - N1. - 163-171 pp.

4 Аюпова Г.В., Федотова А.А., Муринов Ю.И., Романко В.Г. Оптимизация технологии адсорбционного геля методом реологии // Химико-Фармацевтический журнал, 2019. - Т. 44. - № 7. - С. 40-43.

5 Ишевский А.Л., Успенская М.В., Гунькова П.И., Давыдов И.А., Василевская И.А. Направления использования альгинатов в пищевой промышленности (Обзор) // Бюллетень Санкт-Петербургского технологического университета. 2018. - № 50. - С. 23-28.

6 Щипунов Ю.А., Конева Е.Л., Постнова И.В. Гомогенные альгинатные гели: фазовое поведение и реологические свойства // Высокомолекулярные соединения. Серия А, 2002. - Т.44. - №7. - С. 12071211.

7 Виноградов Г.В., Малкин А.Я. Реология полимеров. - Москва, 1997. - 2015 с.

8 Усов А. И. Альгиновые кислоты и апьгинаты: методы анализа, определения состава и установления строения // Усп. хим, 1999. - Т. 68. - № 11. - С. 1051-1061.

9 Аминина, Н.М. Альгинаты: состав, свойства, применение / Н.М. Аминина, А.В Подкорытова // Известия ТИНРО, 1995. - Т. 118. - С. 130-137.

10 Попков, В.А. Влияние твердых дисперсий на растворимость лекарственных веществ / В.А. Попков, И.И. Краснюк, В.Ю. Решетняк, Ю.В. Сковпень // Фармация, 2004. - № 1. - С. 17-21.

11 Кирьянова, А.А. Использование гидроколлоидов в производстве кондитерских изделий / А.А. Кирьянова, И.Л. Корецкая // Хлебопекарское и кондитерское дело, 2009. - № 4. - С. 38-40.

12 Фогельсон Р.Л., Лихачев Е.Р. Температурная зависимость вязкости // Журнал технической физики. 2001. - T. 71. - № 8. - C. 128-131. 


\title{
REFERENCE
}

1 Kirsanov, E.A., Matveenko, V.N. (2016). Nyutonovskoe povedenie strukturirovannyh sistem [Newtonian behavior of structured systems]. Moskva [in Russian].

2 Muratova, E.I., Smolihina, P.M. (2013) Reologiya konditerskih mass [Rheology of confectionery masses]. Tambov [in Russian].

3 Sousa, A.M., Borges, J., Silva, A.F., Goncalves, M.P. (2013). Influence of Extraction Processing on Rheological and structural properties of calcium. Carbohydrate Polymers.96, 1,163-171.

4 Ayupova, G.V., Fedotova, A.A., Murinov, YU.I., Romanko, V.G. (2019). Optimizaciya tekhnologii adsorbcionnogo gelya metodom reologiirheology of confectionery masses [Optimization of adsorption gel technology by rheology method]. Himiko-Farmacevticheskij zhurnal.44, 7, 40-43. [in Russian].

5 Ishevskij, A.L., Uspenskaya, M.V., Gunkova, P.I., Davydov, I.A., Vasilevskaya, I.A. (2018). Napravleniya ispol'zovaniya alginatov $\mathrm{v}$ pishchevoj promyshlennosti (Obzor) [Directions for the use of alginates in the food industry (Review)]. Byulleten Sankt-Peterburgskogo tekhnologicheskogo universiteta. 50, 23-28. [in Russian].

6 Shchipunov, YU.A., Koneva, E.L., Postnova, I.V. (2002). Gomogennye alginatnye geli: fazovoe povedenie i reologicheskie svojstva [Homogeneous alginate gels: phase behavior and rheological properties]. Vysokomolekulyarnye soedineniya. Seriya A.44,7,1207-1211.[in Russian].

7 Vinogradov, G.V., Malkin, A.YA. (1997). Reologiya polimerov [Rheology of polimers]. Moskva [in Russian]. 8 Usov, A.I. (1999). Alginovye kisloty i apginaty: metody analiza, opredeleniya sostava i ustanovleniya stroeniya [Alginic acids and apyginates: methods of analysis, determination of composition and establishment of structure]. Usp. him. 68,11,1051-1061. [in Russian].

9 Aminina, N.M. (1995). Alginaty: sostav, svojstva, primenenie [Alginates: composition, properties, application] / N.M. Aminina, A.V Podkorytova. Izvestiya TINRO . 118, 130- 137. [in Russian].

10 Popkov, V.A. (2004). Vliyanie tverdyh dispersij na rastvorimost lekarstvennyh veshchestv [Influence of solid dispersions on the solubility of medicinal substances] / V.A. Popkov, I.I. Krasnyuk, V.YU. Reshetnyak, YU.V. Skovpen . Farmaciya. 1,17-21. [in Russian].

11 Kiryanova, A.A. (2009). Ispolzovanie gidrokolloidov v proizvodstve konditerskih izdelij [The use of hydrocolloids in the manufacture of confectionery] / A.A. Kiryanova, I.L. Koreckaya. Hlebopekarskoe i konditerskoe delo. 4, 38-40. [in Russian].

12 Fogelson, R.L., Lihachev, E.R. (2001). Temperaturnaya zavisimost vyazkosti [Temperature dependence of viscosity]. Zhurnal tekhnicheskoj fiziki.. 71, 8, 128-131. [in Russian].

\author{
С.С. Карпова ${ }^{1}$, А.К. Оспанова ${ }^{1}$ \\ ${ }^{1}$ Инновациялық Еуразия университетті, Қазақстан
}

\section{Кальций альгинаты ерітінділері реологиясының концентрацияға, температураға және ығысу жылдамдығына тәуелдігін зерттеу}

Кальций тұздарының реологиялық қасиеттері қазіргі заманғы зерттеуші үшін теориялық және практикалық қызығушылық тудырады. Теориялық қызығушылық, ең алдымен, кальций тұздары ерітінділерінің реологиялық қасиеттерінің жалпы заңдылықтары мен көріністерін іздеумен байланысты. Практикалық компонент ерітінділер қасиеттерінің зерттеу объектісінің құрылымы мен құрамына тәуелділігі мен заңдылықтарын іздеуге негізделген. Кальций тұздары сияқты химиялық заттар ерекше практикалық қызығушылық тудырады, олар тамақ, химия және фармакологиялық индустрия сияқты әртүрлі салаларда кеңінен қолданылады. Альгинаттардың гидрофильді жоғары молекулалық ерітінділері, атап айтқанда кальций алгинаты, жұмсақ дәрілік формаларды дайындауда, кондитерлік өнімдерде желе массаларын өндіруде белсенді қолданылады және тамақ өнеркәсібінде қалыңдатқыш ретінде әрекет етеді. Олар төмен концентрациядағы тұтқырлықтың жоғары пайызымен, биожетімділігімен, ұзаққа созылатын әсерімен, тітіркендіргіш қасиеттерінің болмауымен, көптеген полимерлермен биожетімділігімен ерекшеленеді, бұл әсіресе фармакологиялық салада және медицинада маңызды. Осы мақсаттар үшін кальций тұздарын қолдану қазіргі уақытта өте перспективалы, өйткені бұл органикалық тұздар гель түзілуіне байланысты бірқатар ерекше қасиеттерге ие.

Бұл жұмыста кальций алгинаты ерітінділері реологиясының ерекшеліктерін зерттеу нәтижелері бар. Зерттеу жүргізу үшін 0,1-0,7 \% концентрация диапазоны таңдалды, бұл бөлме температурасында гель түзілуіне жол бермеу үшін жеткілікті. Тұтқырлықтың концентрацияға, температураға $\left(25-45{ }^{\circ} \mathrm{C}\right.$ аралығында) және Ығысу жылдамдығына тәуелділігі зерттелді.

Теориялық дереккөздерді талдау, бақылау, нәтижелерді салыстыру. Алынған заттардың реологиялық сипаттамаларын зерттеу капиллярлық вискозиметрде жүргізілді. Өлшеу 25-45 ${ }^{\circ} \mathrm{C}$ температура диапазонында жүргізілді. Тұтқырлықтың концентрация мен температураға тәуелділігі бар екендігі анықталды. 0,1-0,7 \% концентрациясы үшін 0,1 \% концентрациясы бар ерітінділерге қарағанда ұқсас тәуелділік түрі байқалады . Осы тәуелділіктердің түсіндірмелері ұсынылды.

Түйін сөздер: кальций альгинаты, ерітінді, тұтқырлық, реология. 


\author{
С.С. Карпова ${ }^{1^{*}}$, А.К. Оспанова ${ }^{1}$ \\ ${ }^{1}$ Инновационный Евразийский университет, Казахстан
}

\title{
Исследование зависимостей реологии растворов альгината кальция от концентрации, температуры и скорости сдвига
}

Реологические свойства солей кальция представляют теоретический и практический интерес для современного исследователя. Теоретический интерес связан с поиском общих закономерностей и проявлений реологических свойств растворов солей кальция. Практическая же составляющая основана на поиске закономерностей и зависимостей свойств растворов от строения и состава объекта изучения. Такие химические вещества, как соли кальция вызывают особый практический интерес, они широко применяются в различных областях, таких как пищевая, химическая и фармакологическая индустрии. Гидрофильные высокомолекулярные растворы альгинатов, а именно альгината кальция, активно применяются в приготовлении мягких лекарственных форм, изготовлении желейных масс в кондитерском деле, выступают в качестве загустителей в пищевой промышленности. Они отличаются достаточно высоким процентом вязкости при низких концентрациях, биодоступностью, пролонгирующим эффектом, отсутствием раздражающих свойств, биосовместимостью со многими полимерами, что особенно важно в фармакологической промышленности и медицине. Использование для этих целей солей кальция в настоящее время очень перспективно, поскольку эти органические соли обладают рядом уникальных свойств, связанных с гелеобразованием.

В данной статье содержатся результаты изучения особенностей реологии растворов альгината кальция. Для проведения исследований был выбран диапазон концентраций 0,1-0,7 \%, что является достаточным для избегания гелеобразования при комнатной температуре. Были исследованы зависимость вязкости от концентрации, температуры (в интервале $25-45^{\circ} \mathrm{C}$ ) и скорости сдвига.

Авторами применен анализ теоретических источников, наблюдение, сравнение результатов. Изучение реологических характеристик полученных веществ проводились на капиллярном вискозиметре. Измерения проводились в диапазоне температур $25-45^{\circ} \mathrm{C}$. Была установлена значительная зависимость вязкости от концентрации и температуры. Для концентраций 0,3-0,7\% наблюдается сходный вид зависимости в отличие от растворов с концентрацией $0,1 \%$. Были предложены объяснения данных зависимостей.

Ключевые слова: альгинат кальция, раствор, вязкость, реология.

Date of receipt of the manuscript to the editor: $2021 / 08 / 14$ 